\title{
Private companies in the Netherlands: proposals for law reform
}

\author{
by Frank Wooldridge
}

The besloten vennootschap met beperkte aansprakelheld (BV) was introduced in the Netherlands in 1971, and has proved popular in that country. The legal provisions governing this type of entity were largely the same as those applicable to the naamloze vennootschap (NV or public company), but the implementation of certain recent proposals will result in some significant differences which aim to introduce a more simple and flexible legal regime governing the BV. The new Dutch proposals are somewhat detailed, and new provisions of Dutch law governing public undertakings have also been suggested. The present article is limited to an outline of certain of the proposals governing the private company. It appears that many of these proposals are likely to come into effect in the near future, and may be somewhat controversial.

\section{PROVISIONS REGARDING CAPITAL AND THE PROTECTION OF CREDITORS}

A $\mathrm{t}$ present, a BV has a required minimum capital of 18,000. This requirement is likely to be abolished. It is proposed that Article 178 of Book 2 of the Code should be amended so as to provide that there is no need for a minimum capital. The requirement that an auditor's statement should be provided in the event of a contribution in kind which is contained in Article 204b of Book 2 of the Code will be abolished, but a statement by the founders or directors of a BV concerning such contributions will still be required. It will be possible to denominate the share capital in a currency other than the euro. There would no longer be any requirement for a bank statement in relation to contributions in cash. Furthermore, there would no longer be any need for authorised capital: if there were such capital, the present requirement that at least one fifth of it should be paid up would be abolished. Authorised capital consists of capital which can be issued without any amendment of the articles.

According to Article 2.207c of the Netherlands Civil Code, a BV may give loans for the purpose of the subscription or purchase by third parties of its shares or depositary receipts (certificaten) issued up to an amount which does not exceed the distributable reserves, provided the articles so permit. This restrictive rule will be repealed if the new government proposals are adopted by the Dutch
Parliament. At present, a BV is permitted by Article 2.207(2)(b) to acquire up to 50 per cent of its issued shares. This limitation will be abolished if the new version of Article 2.207(2) comes into force, according to which the purchase of the company's own shares will be impermissible if this will involve the distribution of reserves that the company is required to maintain by the law or the articles, and where the directors foresaw or ought to have foreseen that after such acquisition the company would not continue to be able to pay its debts.

\section{RULES GOVERNING DISTRIBUTIONS}

The rules governing minimum capital have been regarded as inadequate as far as the protection of creditors is concerned. This is also true of certain other rules relating to the safeguarding of capital. The Dutch governmental proposals, which seem to have been influenced by comparative law studies, include the use of a balance sheet test and a liquidity test, which are intended to increase creditor protection and provide for more flexible rules relating to capital maintenance. The balance sheet test and liquidity tests are used in draft Article 207 and 207a of Book 2 of the Dutch Civil Code, which deals with the acquisition by a private company (NV) of its own shares. Draft Article 216 which deals with other distributions by a private company makes use of the liquidity test, and also refers to the balance sheet test. The latter test requires that the amount of the company's 
statutory reserves and the reserves required by the articles shall not be depleted as the result of the distribution. The liquidity test requires that after the distribution, the company shall be able to pay its debts as they fall due. The use of these tests appears to be influenced by the American Revised Model Business Corporation Act.

According to draft Article 207(1), directors have the task of deciding on share buy-backs by the company. By draft Article 207(2) of Part 2 of the Dutch Civil Code, the company may not acquire any shares in itself if this would lead to a depletion of the reserves that the company must maintain by law or its articles; or if the directors know or should reasonably anticipate that after such acquisition, the company cannot cover its debts as they fall due.

Draft Article 207(3) of Part 2 of the Dutch Civil Code appears of considerable importance, and is of a very detailed character. The first sentence of this article provides that if it transpires that after the company has acquired shares in itself, it cannot pay its debts as they fall due, directors who knew or ought to have known of this situation are jointly and severally liable to the company for the purchase price together with interest at the statutory rate. A director who could demonstrate that he did not know or ought to have known of the wrongful distribution, and was not negligent in taking measures to avoid its consequences, would be exonerated from liability.

Draft Article 207(3) will also apply to shadow directors. If the company acquires certain of its own shares within one year of becoming bankrupt, and the transferor thereof knows or ought to have known that the company could not pay its debts as they fell due, the transferor is liable to the company for the price of the shares plus interest at the statutory rate. If the directors had discharged their liability in accordance with the first sentence of draft Article 207(3), their liability under the previous sentence 3 would be proportionately reduced. Draft Article 207 of Book 2 of the Dutch Civil Code will also apply to certificaten.

The rules contained in draft Article 216 of Book 2 are somewhat more complex than those contained in draft Article 207, but they are of a generally similar character in many respects. They apply to distributions in general as opposed to distributions made to a shareholder whose shares are acquired by the company.

According to draft Article 216(1), the general meeting is required when determining the income available in accordance with the annual accounts, and in determining expenditures, to ensure that the net equity (eigen vermogen) is greater than the reserves which have to be maintained as the result of legal requirements and the articles. By draft Article 216(2) the general meeting cannot decide upon any expenditure until the directors have approved it. This draft provision also requires the directors to refuse such consent if they know or reasonably anticipate that after the distribution has been made, the company will be unable to pay its debts as they fall due. Draft Article 216(3) of Book
2 of the Dutch Civil Code is in generally similar terms to Article 207(3), and is of comparable complexity. Sentence 1 of this article provides that if the directors are aware or should reasonably anticipate that after making a distribution (uitkering) it will be impossible for the company to pay its debts as they fall due, the directors will be jointly and severally liable for the amount or value of the distribution together with interest at the statutory rate. No such liability is imposed on a director who could show that he did not know or ought to have known of the wrongful distribution. Draft Article 216(3) will also apply to shadow directors.

According to sentence 3 of draft Article 216(3), if the company makes a distribution within one year of the opening of bankruptcy proceedings, a person who receives a distribution within this period of time and who is aware, or who may be reasonably anticipated to know that after such distribution, the company cannot pay its debts as they fall due, must return the amount of the distribution to the company together with interest at the statutory rate. The directors may also be held liable to make such restitution to the company, but their liability would be proportionately reduced if they had satisfied their liability under sentence 1 of draft Article 216(3).

The new proposed rules governing distributions would appear to impose a considerable burden on directors. Certain aspects of thee proposals proposals are considered in an article by L Lennarts, ("Directors and Shareholders' Liability: Protecting Creditors of the BV", 8 EBLR 131, 138-41). It has been suggested that in some cases the accounts may be somewhat out of date and that the period to which the liquidity test refers might be limited. It remains to be seen whether the provisions regarding distributions will undergo some modification before the enactment of the new statute. They would appear to be the most interesting and important elements of the proposed revisions of the legal regime governing the BV which has been influenced by comparative law studies. Certain other aspects of these proposals will be briefly mentioned below. These include shares and their transfer and the settlement of disputes.

\section{SHARES AND THEIR TRANSFER}

A BV may issue shares of different classes. It follows from draft Article 228(5) of Book 2 of the Netherlands Civil Code that voteless shares may be issued. This draft provision stipulates that shares of a particular class may be deprived of their vote if all the shareholders agree. Otherwise, voteless shares may be issued if the articles provide for the issues of such shares before lot advance. According to draft Article 192, the articles may impose additional obligations upon all shares or shares of a particular class towards the other shareholders or the company itself. 
Article 2.195 of the Dutch Civil Code used to require the imposition of transfer restrictions on the shares in a private company: such a restriction is often thought of as reflecting the personalistic nature of the company. The former mandatory blocking clause will, according to the new draft form of Article 195, no longer be necessary. The company will be permitted to choose freely transferable shares, or give existing shareholders a first right of refusal, or require the agreement of the directors or the general meeting for such transfers. However, it follows from draft Article 195(5) of Book 2 of the Netherlands Civil Code that such transfer may not be rendered impossible, or unduly difficult (onmogelijk of uiterst bezwaarlijk). There are no major new proposals governing the management or supervisory boards of Dutch private companies, including large ones.

\section{DISPUTE SETTLEMENT}

Articles 335-343 of Book 2 of the Civil Code provide for the remedy of compulsory purchase or compulsory sale of shares in private companies and in closely held public companies which limit the transfer of shares in the same way as a public company. Such companies must only have registered shares and issue no bearer depository certificates. This remedy has not been much used in practice, because of many procedural difficulties enabling reluctant parties to delay the proceedings for years by initiating appeal procedures. Many of the relevant provisions will be revised if the proposed amendments to Part 2 of the Dutch Civil Code come into effect.

The above amendments will permit the company and its shareholders to adopt dispute settlement procedures in the company's articles or by agreement. It follows from the new Article 337 of Book 2 of the Dutch Civil Code that the company must be able to make its own arrangements for settlement and depart from all or certain of the statutory provisions, unless that arrangement would render the transfer of shares impossible or extremely difficult. It will be possible for disputes to be settled by the Enterprise Chamber of the Court of Appeal of Amsterdam or by arbitration. According to proposed new Article 339(3) of Book 2 of the Dutch Civil Code the court will not be required to appoint experts to determine the price of the shares of an oppressed shareholder who wishes to leave the company if it can determine it itself, which would be the case if the parties agree on the price of the shares, or the agreement between the company and the shareholders contains clear criteria for establishing their value. A shareholder whose rights or interests have been prejudiced through the actions of other shareholders to the extent that he can no longer reasonably be expected to remain a member will, according to draft Article 2.343(1) of the Dutch Civil Code, be able to be bought by such shareholders in the company. Draft Article 2.343(4) of Book 2 of the Dutch Civil Code will enable a shareholder who wishes to be bought to request the court to take account of a depreciation in the value of shares caused by the activities of the other shareholders or in the company itself. The provisions governing the settlement of disputes by the company will also make it clear that a shareholder who prejudices the interests of the company may also be bought out.

The new provisions may well increase the popularity of the Dutch BV, which may come into frequent use as a subsidiary in other states, as also has the British limited company in Germany following the decisions of the Court of Justice in Centros (Case C212/97 (1999) ECR1-1459) and Inspire Art (Case C-167/02 (2003) ECRI-10155). However, it should be remembered that Dutch company law contains a number of rather stringent and complex provisions, which may not always be found welcome by a subsidiary of a foreign company. The need for the use of a notarial form increases the expense of forming such a company.

Dr Frank Wooldridge 